\title{
Modelling physical injury to vehicle inhabitants - test methodologies and occupant survivability design requirements
}

\author{
L. A. Young \& T. J. Walilko \\ Applied Research Associates, Inc., USA
}

\begin{abstract}
For thirty-five years the automotive safety community has been collecting event data, performing tests and applying numerical modelling methods with the single objective of reducing injuries and fatalities caused by motor vehicle crashes. These efforts have resulted in countless design modifications that have increased the crashworthiness of automobiles worldwide, reducing fatalities by almost $70 \%$ and saving an estimated 1.9 million lives in the United States alone since 1965. As military and civilian armoured vehicle designers seek to improve occupant survivability, they must build upon these life-saving technologies to produce vehicles that are not only "crashworthy," but also "blast-worthy." This paper describes a methodology for providing quantitative, objective blast-mitigating vehicle design requirements, then offers test methods and injury criteria that can be used to evaluate the effectiveness of a vehicle at satisfying these requirements. Existing anthropomorphic test devices and associated injury criteria are discussed in terms of their applicability in a blast environment, and for high-risk test conditions, ruggedized and more cost-effective alternatives to anthropomorphic test devices are offered.
\end{abstract}

Keywords: vehicle safety, occupant survivability, testing, explosions.

\section{Introduction}

In today's climate of combating terrorism, civilian and military vehicles that are both crashworthy and blast-worthy have become increasingly in demand. While crashworthy design, testing and evaluations have been a standard part of civilian automotive engineering for over 35 years, blast-worthiness is a relatively new challenge, requiring that a vehicle not only be capable of mitigating impact loads 
on occupants, but also ballistic (fragmentation) and shock overpressure effects. To ensure that new vehicle designs adequately meet occupant survivability requirements, blast-worthiness requirements must be objective and quantitative; standardized test methodologies must be adopted which offer quantitative means of evaluating vehicle designs.

The following paragraphs provide an overview of a methodology for establishing occupant survivability requirements that are quantitative and medically grounded. A suite of tests is recommended, allowing verification of both blast and crashworthiness of armoured vehicles using existing test equipment. Finally, shortfalls in the existing test equipment are identified, thus providing insight into future research requirements.

\section{Occupant survivability requirements}

Typically, occupant survivability requirements are described in terms of either a subjective, post-event functional "status" for vehicle occupants, or a vehicle response, from which occupant status is inferred. Examples of such requirements are:

- All vehicle occupants must survive;

- All vehicle occupants must not be incapacitated; or

- An Explosively Formed Projectile (EFP) must not be able to penetrate.

One problem with these types of requirements statements is that they are subjective. For example, incapacitation is not defined except in the context of a job or mission; what qualifies as an incapacitating injury for one passenger may not be incapacitating for another. Another problem with these requirement statements is that they may lead to over or under-design of a vehicle. For example, perhaps it is acceptable for an EFP to perforate the vehicle, if sufficient energy is absorbed by the penetration process that the residual EFP is benign. Or, perhaps it is insufficient for an EFP to be stopped by the vehicle hull, if the impact creates a severe behind-armour debris (BAD) environment. A third problem with these types of requirements is that they are not quantitative, making it difficult to experimentally verify the sufficiency of a vehicle design.

To support design of a vehicle that is both crashworthy and blast-worthy, design requirements are needed that meet four conditions: (1) quantitative, (2) objective, (3) relevant to some post-event status objective and (4) experimentally verifiable.

\subsection{Maximum abbreviated injury scale}

The first two of these conditions are met when we exploit the Maximum Abbreviated Injury Scale (MAIS) scoring system to define medically-based occupant safety requirements. The MAIS scoring system is predicated on the Abbreviated Injury Scale (AIS) which is an anatomically-based, consensusdriven global severity scoring system for individual injuries grouped by levels of ascending severity, AAAM [2]. The first part of the AIS number is a six-digit injury descriptor known as the pre-dot code; the second part (the post-dot code) contains the severity score for each injury by body region, according to its 
relative importance on a 6 -point ordinal scale (i.e., $1=$ minor, $2=$ moderate, $3=$ serious, $4=$ severe, $5=$ critical, $6=$ maximal [currently untreatable]).

The MAIS score is the highest AIS severity score, when multiple injuries are present, and has been used for many years as an effective abbreviated method for assessing overall injury severity and probability of survival, Meredith [3]. MAIS is a simple, reliable indicator of outcome that is used extensively in vehicle crash, general morbidity/mortality, and combat injury classification and analysis.

\subsection{Relationship between MAIS and incapacitation}

The third condition, relevance to some post-event occupant status, is being addressed in on-going research in the United States to establish a pre-defined relationship between the MAIS scores and key levels of functionality for military applications. The post-event conditions that have been defined are:

1. No Injury

2. Injured but able to continue immediate mission

3. Injured and able to contribute to the missions, although not fully functional

4. Immediate loss to the mission but only for the short-term

5. Immediate loss to the mission and unavailable for the long-term

6. Lost to the military

7. Deceased

Although additional work is required to confirm the relationships between MAIS scores and incapacitation, MAIS 1 and 2 will correspond approximately to the functional incapacitation levels 2 and 3 above; MAIS 3 will correspond approximately to functional incapacitation level 4. Although these particular definitions of functionality are specific to the military, similar functionality definitions can be established for civilian applications.

\subsection{Injury criteria}

Finally, the fourth desired quality of a performance requirement, that it be experimentally verifiable, is met through the use of injury criteria with a known relationship to AIS scores. Broadly speaking, injury criteria are functions that relate measurable parameters, such as force, deflection or acceleration to known injuries. As an example, the Neck Injury Criterion (Nij) is a function of axial loading and bending moments, measured using the neck of the Hybrid III anthropomorphic test device (ATD), which is used to determine the conditions under which a neck injury is incurred as a result of differential motion between the head and the body.

With varying degrees of validation available in the blast environment, injury criteria exist for most of the major sources of injury to vehicle occupants in a blast event: fire, fragment or debris penetration and blunt trauma for local and global vehicle motion. Military, automotive and sports research offer decades of data and methodology development work, upon which a MAIS-to-injury criteria relationship is based. The values are mostly applicable to the Hybrid III $50^{\text {th }}$ percentile male dummy for various body regions. 
Tables 1 and 2 provide a list of sample injury criteria, with values for assumed incapacitation objectives and MAIS requirements. Actual numerical values will vary for each vehicle design; however, these tables provide an illustration of how subjective post-event functional capacity objectives can relate to quantitative MAIS objectives and associated injury criteria.

\section{Test methods}

Perhaps the most important and difficult aspects of survivability-based armoured vehicle design is experimental verification that a given vehicle meets survivability requirements. Because an armoured vehicle must be effective at protecting occupants from blast threats, ballistic threats and automotive crashes, a comprehensive armoured vehicle test program evaluates vehicle performance through a series of tests which independently address each of these potential insults (Walilko [17]): (1) Ballistics; (2) Roadside improvised explosive devices (IEDs) and lateral bulk explosive; (3) Landmines and under-belly bulk explosives; and (4) Motor vehicle accidents - frontal, side and rear impact, rollover.

Although there currently does not exist an international standard for occupant survivability testing on armoured vehicles loaded by blast, there are some best practices that have been adopted in recent years.

\subsection{Human surrogates}

Occupant survivability testing requires the use of human surrogates, which are non-biological substitutes for the human body that have a similar geometry,

Table 1: $\quad$ Sample performance requirements.

\begin{tabular}{|c|c|c|c|c|c|c|}
\hline \multirow[b]{2}{*}{ Threat } & \multirow[b]{2}{*}{$\begin{array}{l}\text { Injury } \\
\text { Mechanism }\end{array}$} & \multicolumn{3}{|c|}{ Medical Objective } & \multicolumn{2}{|c|}{ Injury Metrics } \\
\hline & & AIS Level & Injury & $\begin{array}{l}\text { Operational } \\
\text { Capacity }\end{array}$ & $\begin{array}{l}\text { MAIS- } \\
\text { Based } \\
\text { Injury } \\
\text { Criteria }\end{array}$ & Test Method \\
\hline \multirow{2}{*}{$\begin{array}{l}\text { Blast } \\
\text { Overpressure } \\
\text { (Primary) }\end{array}$} & \multirow{2}{*}{$\begin{array}{l}\text { Pressure } \\
\text { inside the } \\
\text { vehicle }\end{array}$} & $\begin{array}{l}\text { Objective: } \\
\text { AIS }<1\end{array}$ & $\begin{array}{l}\text { Temporary } \\
\text { hearing loss }\end{array}$ & \multirow{2}{*}{$\begin{array}{l}\text { Decreased } \\
\text { communication } \\
\text { capacity }\end{array}$} & \multirow{2}{*}{$\begin{array}{l}\text { AHAAH } \\
\text { Model, } \\
\text { Price [4] }\end{array}$} & \multirow{2}{*}{$\begin{array}{l}\text { Pressure } \\
\text { gages inside } \\
\text { the vehicle }\end{array}$} \\
\hline & & $\begin{array}{l}\text { Threshold } \\
: \text { AIS }<2\end{array}$ & $\begin{array}{l}\text { Ear Drum } \\
\text { Rupture }\end{array}$ & & & \\
\hline \multirow{2}{*}{$\begin{array}{l}\text { Fragmentation } \\
\text { (Secondary) }\end{array}$} & \multirow{2}{*}{ Penetration } & $\begin{array}{l}\text { Objective: } \\
\text { AIS }<2\end{array}$ & $\begin{array}{l}\text { Minor } \\
\text { extremity } \\
\text { penetration }\end{array}$ & $\begin{array}{l}\text { Cannot fire a } \\
\text { weapon }\end{array}$ & \multirow{2}{*}{$\begin{array}{l}\text { ORCA / } \\
\text { Computer } \\
\text { Man, } \\
\text { Saucier [5] }\end{array}$} & \multirow{2}{*}{$\begin{array}{l}\text { Plywood } \\
\text { Man, Davis } \\
6]\end{array}$} \\
\hline & & $\begin{array}{l}\text { Threshold } \\
\text { AIS }<4\end{array}$ & $\begin{array}{l}\text { Significant } \\
\text { penetration }\end{array}$ & $\begin{array}{l}\text { Requires } \\
\text { medical } \\
\text { assistance }\end{array}$ & & \\
\hline \multirow{2}{*}{$\begin{array}{l}\text { Gross Vehicle } \\
\text { Motion (Tertiary } \\
\text { or Motor } \\
\text { Vehicle Crash) }\end{array}$} & \multirow{2}{*}{$\begin{array}{l}\text { Acceleration } \\
\text { and Impact }\end{array}$} & $\begin{array}{l}\text { Objective: } \\
\text { AIS }<2\end{array}$ & \multirow{2}{*}{ Blunt Trauma } & \multirow{2}{*}{$\begin{array}{l}\text { Loss of } \\
\text { mobility and } \\
\text { cognitive } \\
\text { deficits }\end{array}$} & \multirow{2}{*}{$\begin{array}{l}\text { Body- } \\
\text { region } \\
\text { specific. } \\
\text { See Table } \\
2\end{array}$} & \multirow{2}{*}{$\begin{array}{l}\text { Automotive } \\
\text { ATD }\end{array}$} \\
\hline & & $\begin{array}{l}\text { Threshold } \\
: \text { AIS }<3\end{array}$ & & & & \\
\hline $\begin{array}{l}\text { Fire and } \\
\text { Thermal } \\
\text { Loading } \\
\text { (Quaternary) }\end{array}$ & Burns & $\begin{array}{l}\text { Threshold } \\
: \text { AIS }<3\end{array}$ & Burns on body & $\begin{array}{l}\text { Requires } \\
\text { medical } \\
\text { assistance }\end{array}$ & $\begin{array}{l}\text { BURNSI } \\
\text { M, Knox } \\
{[7]}\end{array}$ & $\begin{array}{l}\text { Heat flux } \\
\text { gage }\end{array}$ \\
\hline
\end{tabular}


Table 2: $\quad$ Sample detailed tertiary/motor vehicle crash performance requirements.

\begin{tabular}{|c|c|c|c|c|}
\hline \multicolumn{3}{|c|}{ Medical Objective } & \multicolumn{2}{|l|}{ Injury Metrics } \\
\hline AIS Level & Injury & Operational Capacity & $\begin{array}{l}\text { MAIS-Based Injury } \\
\text { Criteria }\end{array}$ & $\begin{array}{l}\text { Test } \\
\text { Method }\end{array}$ \\
\hline \multicolumn{5}{|c|}{ General Gross Vehicle Motion } \\
\hline $\begin{array}{l}\text { Objective: } \\
\text { AIS }<2\end{array}$ & Concussion & \multirow{2}{*}{$\begin{array}{l}\text { Varying levels of } \\
\text { cognitive deficit }\end{array}$} & $\mathrm{HIC}<250$, Prasad[8] & \multirow{6}{*}{$\begin{array}{l}\text { HYBRID } \\
\text { III ATD, }\end{array}$} \\
\hline $\begin{array}{l}\text { Threshold: } \\
\text { AIS }<3\end{array}$ & Traumatic Brain Injury & & $\mathrm{HIC}<700$ & \\
\hline $\begin{array}{l}\text { Objective: } \\
\text { AIS }<2\end{array}$ & Injury to Chest Wall & \multirow{2}{*}{$\begin{array}{l}\text { Loss of mobility, requires } \\
\text { medical assistance }\end{array}$} & \multirow{2}{*}{$\begin{array}{l}\text { TTI }<85 \text {, Eppinger [9] } \\
3 \mathrm{~ms} \text { Clip }<60 \mathrm{~g} \text {, Viano } \\
{[10]}\end{array}$} & \\
\hline $\begin{array}{l}\text { Threshold: } \\
\text { AIS }<3\end{array}$ & $\begin{array}{l}\text { Injury to Chest Wall with } \\
\text { Moderate Internal Injuries }\end{array}$ & & & \\
\hline $\begin{array}{l}\text { Objective: } \\
\text { AIS }<2\end{array}$ & \multirow{2}{*}{ Pelvic fracture } & \multirow{2}{*}{$\begin{array}{l}\text { Loss of mobility, requires } \\
\text { medical assistance }\end{array}$} & \multirow{2}{*}{$\begin{array}{l}\text { Pelvis Accl < 130g, Leport } \\
\text { [11] }\end{array}$} & \\
\hline $\begin{array}{l}\text { Threshold: } \\
\text { AIS }<3\end{array}$ & & & & \\
\hline \multicolumn{5}{|c|}{ Side-Wall Intrusion } \\
\hline $\begin{array}{l}\text { Objective: } \\
\text { AIS }<2\end{array}$ & Concussion & \multirow{2}{*}{$\begin{array}{l}\text { Varying levels of } \\
\text { cognitive deficit }\end{array}$} & $\mathrm{HIC}<250$ & \multirow{6}{*}{$\begin{array}{l}\text { SID OR } \\
\text { EUROSID } \\
\text { ATD }\end{array}$} \\
\hline $\begin{array}{l}\text { Threshold: } \\
\text { AIS }<3\end{array}$ & Traumatic Brain Injury & & $\mathrm{HIC}<700$ & \\
\hline $\begin{array}{l}\text { Objective: } \\
\mathrm{AIS}<2\end{array}$ & Injury to Chest Wall & \multirow{2}{*}{$\begin{array}{l}\text { Loss of mobility, requires } \\
\text { medical assistance }\end{array}$} & \multirow{2}{*}{$\begin{array}{l}\text { TTI }<85 \\
3 \text { ms Clip }<60 \mathrm{~g}\end{array}$} & \\
\hline $\begin{array}{l}\text { Threshold: } \\
\text { AIS }<3\end{array}$ & $\begin{array}{l}\text { Injury to Chest Wall with } \\
\text { Moderate Internal Injuries }\end{array}$ & & & \\
\hline $\begin{array}{l}\text { Objective: } \\
\text { AIS }<2\end{array}$ & \multirow[t]{2}{*}{ Pelvic fracture } & \multirow[t]{2}{*}{$\begin{array}{l}\text { Loss of mobility, requires } \\
\text { medical assistance }\end{array}$} & \multirow[t]{2}{*}{ Pelvis Accl $<130 \mathrm{~g}$} & \\
\hline $\begin{array}{l}\text { Threshold: } \\
\text { AIS }<3\end{array}$ & & & & \\
\hline \multicolumn{5}{|c|}{ Floorboard Upward Intrusion } \\
\hline $\begin{array}{l}\text { Objective: } \\
\text { AIS }<2\end{array}$ & Ankle Fracture & \multirow[t]{2}{*}{$\begin{array}{l}\text { Loss of mobility, requires } \\
\text { medical assistance }\end{array}$} & $\begin{array}{l}\text { Axial Tibia Load }<5400 \\
\text { N, Hirsch [15] }\end{array}$ & $\begin{array}{l}\text { HYBRID } \\
\text { III ATD } \\
\text { with High- } \\
\text { Fidelity } \\
\text { Leg }\end{array}$ \\
\hline $\begin{array}{l}\text { Threshold: } \\
\text { AIS }<3\end{array}$ & $\begin{array}{l}\text { Vertebral Fracture of } \\
\text { Lumbar Spine }\end{array}$ & & $\begin{array}{l}\text { Axial Lumbar Load < } \\
6700 \mathrm{~N}, \text { Horst [16] }\end{array}$ & $\begin{array}{l}\text { HYBRID } \\
\text { III ATD }\end{array}$ \\
\hline
\end{tabular}

weight and mass distribution to the human body. Surrogates typically, but not necessarily, have a bio-fidelic response similar to the human, but a simple mannequin can sometimes be used as a suitable surrogate.

For automotive applications, the preferred bio-mechanical surrogates are ATDs. ATDs are constructed with a steel skeleton and rubber elements, surrounded by rubber and foam material to simulate the skin and soft tissue. The material properties of the skin and soft tissue, like stiffness and damping, influence the internal loads during impact or loading transfer.

Automotive ATDs are one of the primary test devices used in blastworthiness testing. However, because they are expensive and highly vulnerable to penetration, for tests where fragment penetration is a high risk, another commonly used test device is the plywood mannequin, or "Plywood Man." It has been calibrated so it is possible to estimate the impact velocity from the mass, shape and depth of penetration of a fragment. Table 3 describes several of the common test devices used in vehicle blast-worthiness testing. 
Table 3: $\quad$ Human surrogates (Walilko [17]).

\begin{tabular}{|c|c|c|}
\hline $\begin{array}{l}\text { Test } \\
\text { Device }\end{array}$ & Picture & Overview \\
\hline $\begin{array}{l}\text { Plywood } \\
\text { Man }\end{array}$ & & $\begin{array}{l}\text { Description: DoD-developed and validated surrogate constructed of } \\
\text { high-grade plywood, with the basic dimensions of a } 50^{\text {th }} \text { percentile } \\
\text { man. The live-fire test standard in the US. } \\
\text { Advantages: An inexpensive surrogate for collecting metal } \\
\text { fragments generated by the device. } \\
\text { Disadvantages: Cannot collect data on non-metallic fragments such } \\
\text { as secondary debris. }\end{array}$ \\
\hline $\begin{array}{l}\text { Blast Test } \\
\text { Device } \\
\text { (BTD) }\end{array}$ & & $\begin{array}{l}\text { Description: Four pressure gages arranged around the } \\
\text { circumference of a cylinder. The gage data are analyzed using the } \\
\text { INJURY model. } \\
\text { Advantages: Validated with over } 1200 \text { head of sheep for } \\
\text { conventional and thermobaric explosives. Applicable to both free- } \\
\text { field and complex blast environments. Reusable and easy to } \\
\text { manufacture. } \\
\text { Disadvantages. Tends to obstruct other types of data recording } \\
\text { equipment in enclosed test environments. Limited applicability for } \\
\text { evaluation of personal protective equipment (PPE). }\end{array}$ \\
\hline $\begin{array}{l}\text { Human } \\
\text { Surrogate } \\
\text { Torso } \\
\text { Model } \\
\text { (HSTM) }\end{array}$ & & $\begin{array}{l}\text { Description: Polymeric } 50 \text { th percentile male torso surrogate } \\
\text { including heart, ribs, liver, stomach, muscle and skin. Bones } \\
\text { fabricated to have the correct tensile properties with organs } \\
\text { designed to have the proper density and stiffness. Can be } \\
\text { extensively instrumented. } \\
\text { Advantages: Reusable and easily instrumented. Same size and } \\
\text { shape as a human. Can be used for comparing Live fire data to data } \\
\text { collected using our in vivo porcine injury model. } \\
\text { Disadvantages: Not validated. }\end{array}$ \\
\hline $\begin{array}{l}\text { HYBRID } \\
\text { III }\end{array}$ & & $\begin{array}{l}\text { Description: Anthropomorphic test device developed for the } \\
\text { automobile safety community to evaluate the likelihood of potential } \\
\text { injuries in frontal crash tests. } 2 \text { The most widely used Hybrid III } \\
\text { (H-III) dummy is the 50th percentile male, which represents the } \\
\text { average male, defined as 5'-10' tall with a } 170 \text { lbs weight. The H- } \\
\text { III is anthropometrical correct and equipped with a bio-fidelic torso } \\
\text { and arms, legs and head. Special H-III editions also include } \\
\text { complex spinal columns. } \\
\text { Advantages: Surrogate is relatively robust. Instrumented at } 150 \\
\text { locations in critical regions of the body. Accelerometers, loadcell } \\
\text { and displacement sensors collect repeatable data that can then be } \\
\text { used to assess the likelihood and severity of injuries. The } \\
\text { mechanical response, however, is not bio-fidelic. Can be fitted with } \\
\text { protective clothing. } \\
\text { Disadvantages: Not validated for the blast environment. The chest } \\
\text { wall is too stiff under high-rate loads. Intended for use with injury } \\
\text { criteria developed by the automotive test community and therefore } \\
\text { its applicability to the blast environment might be limited and } \\
\text { should be carefully evaluated. Cost is in excess of } \$ 100 \mathrm{~K} \text {. }\end{array}$ \\
\hline
\end{tabular}




\subsection{Ballistics}

For occupant protection against ballistic munitions, tests should be conducted on vehicle armour configurations expected at the final delivery. Multiple shots, in a specific shot pattern, should be performed on each vehicle, and the resulting vehicle performance should be provided in terms of ballistic resistance which measure the vehicles capacity to stop or reduce the striking velocity and mass of the projectile. In most cases, performance requirements for armoured vehicles require that no fragments perforate the vehicle hull. However, to verify occupant survivability in vehicle-overmatch conditions or where there is concern about behind armour debris (e.g. EFP penetration), the Plywood Man should be placed inside the vehicle.

\subsection{Roadside IEDs and lateral bulk explosives}

To evaluate survivability against a roadside bomb, usually two separate tests are recommended: lateral bulk and roadside IEDs. The reason for conducting two separate tests is that the roadside IED tests are likely to produce casing fragments that would be destructive to the ATDs needed to evaluate blunt impact injuries. Therefore, lateral bulk tests should also be performed, using an uncased explosive and ATDs to evaluate the blunt impact effects on vehicle occupants. Roadside IED tests should be performed using the cased charge and Plywood Man to evaluate the fragmentation effects on vehicle occupants. Of course, if the threat to the vehicle is not likely to produce significant fragmentation, the lateral bulk tests can be eliminated.

Both the lateral bulk and roadside IED tests should be conducted on a vehicle armoured as it will be in the field. As shown in Figure 1, the minimal roadside IED or lateral bulk test configuration includes a high-speed video (HSV) camera, high-speed heat flux gages to characterize the thermal content of the blast and at least one pressure gage to characterize the shock wave at the same standoff distance as the vehicle.

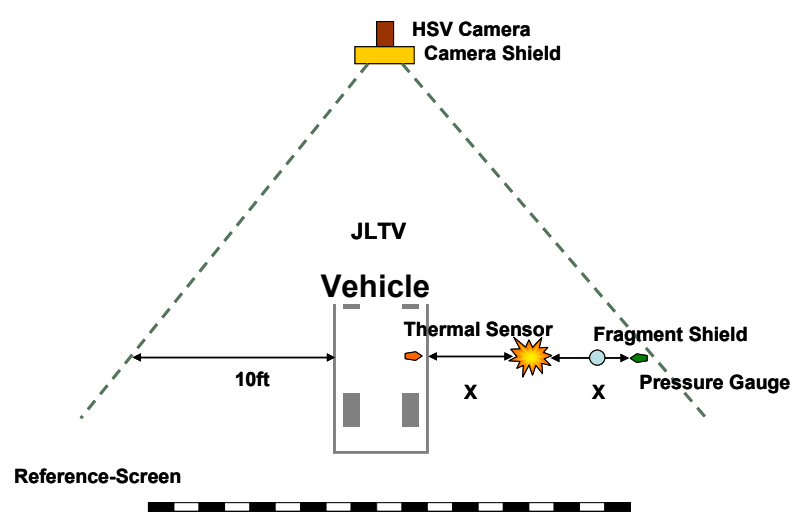

Figure 1: Roadside IED and lateral bulk test configuration. 
On the vehicle itself (Figure 2), instrumentation should include one or more linear accelerometers to capture the gross vehicle motion. Thermocouples should be used to characterize the thermal loading environment on the interior of the vehicle. High rate displacement gages may also be useful on the vehicle sidewall facing the charge, to capture the elastic motion of the sidewall during the blast event. Additionally, although the internal overpressure environment is rarely sufficient to cause more than ear damage, one or more pressure gage can be placed inside the vehicle to capture the internal blast environment, as well.

Although the actual values will vary, depending upon the survivability objectives established by the vehicle designers, Table 4 provides sample pass-fail criteria for roadside IED tests.

The primary distinction between the roadside IED and lateral bulk tests is the choice of human surrogates. For the roadside IEDs, where fragmentation is a risk, the Plywood Man is the preferred surrogate. For lateral bulk tests, where fragmentation is not a significant risk, the more bio-fidelic Side Impact Dummy (SID) or the European version of the SID (Euro-SID) is preferred.

Vehicle pass-fail criteria for the lateral-bulk tests will be similar to the roadside tests. Table 5 provides sample pass-fail criteria for the SID surrogates.

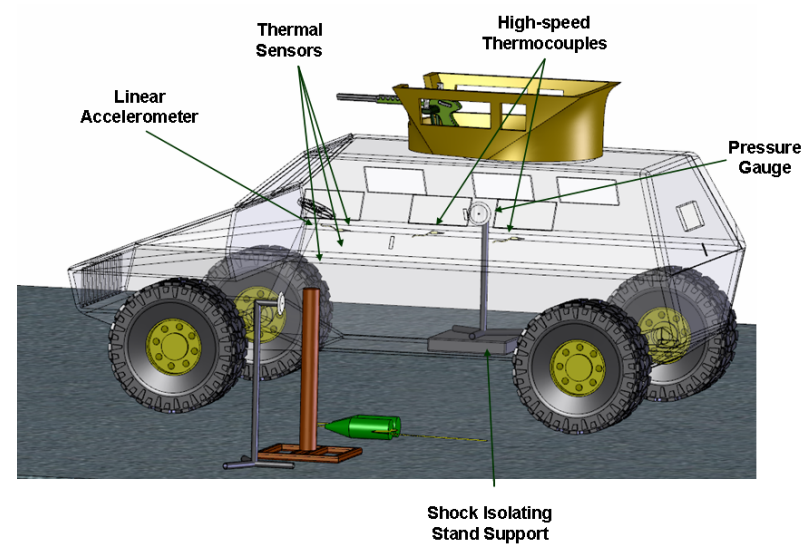

Figure 2: $\quad$ Roadside IED and lateral bulk vehicle set-up.

Table 4: $\quad$ Pass-fail criteria for roadside device tests.

\begin{tabular}{|l|l|l|}
\hline Measure & Requirement & Rationale \\
\hline Post-test vehicle operation & Travel 2km within 2-minutes, without stopping & \\
\hline Overpressure & Peak incident pressure $<50 \mathrm{kPA}$ & Threshold requirement, James [18] \\
\hline Heat flux & $\begin{array}{l}\text { Heat flux }<16.3 \mathrm{~J} / \mathrm{cm}^{2} \text { for areas of exposed skin } \\
\text { and } 38.5 \mathrm{~J} / \mathrm{cm}^{2} \text { for covered areas }\end{array}$ & $2^{\text {nd }}$ degree burn threshold, Knox [7] \\
\hline \multirow{5}{*}{ Penetration } & $\begin{array}{l}\text { Armour should not be deformed or breached. } \\
\text { Resulting gap }<25 \mathrm{~mm} \text { in width } \\
\text { Energy density of penetrating fragments }<24 \\
\mathrm{~J} / \mathrm{cm}^{2}\end{array}$ & $\begin{array}{l}\text { No Skin Penetration Allowed, Bir } \\
{[19]}\end{array}$ \\
\hline \multirow{3}{*}{ Impact } & $\begin{array}{l}\text { Measured wall displacement shall not exceed } \\
\text { distance to nearest occupant location } \\
\text { Velocity of interior side walls }<5 \mathrm{~m} / \mathrm{s}\end{array}$ & $\begin{array}{l}\text { Proposed based on Limited } \\
\text { Numerical Modelling }\end{array}$ \\
\hline
\end{tabular}




\subsection{Landmines and underbelly bulk explosives}

As with roadside IEDs, evaluations of occupant survivability for blast devices underneath the vehicle should be evaluated with two tests. The landmine tests are used for capturing fragmentation data with plywood mannequins, and the underbelly bulk explosive tests are used for capturing blunt trauma with ATDs. Again, if the threat to a vehicle is not likely to produce armour-perforating fragmentation, the lateral bulk tests can be eliminated.

Table 5: $\quad$ SID performance requirements for the lateral bulk tests.

\begin{tabular}{|l|l|l|}
\hline Head/Neck & Criteria & Rationale \\
\hline Head Injury Criteria & 700 & FMVSS 214 [20] \\
\hline Neck Injury Criteria & 1.0 & FMVSS 214 \\
\hline Torso & Criteria & \\
\hline Spine Acceleration & $60 \mathrm{~g}$ & FMVSS 214 \\
\hline Rib Displacement & $64 \mathrm{~mm}$ & FMVSS 214 \\
\hline Viscous Criteria & 1.0 & (Alt) Lau 1986 [21] \\
\hline Thoracic Trauma Index & 85 & FMVSS 214 \\
\hline Pelvis & Criteria & \\
\hline Axial Lumbar load & $6800 \mathrm{~N}$ & \\
\hline Acceleration & $130 \mathrm{~g}$ & FMVSS 214 \\
\hline Dynamic Response Index & 16 & NATO 2006 [22] \\
\hline Lower Extremities & Criteria & \\
\hline Tibia Axial Force & $5,400 \mathrm{~N}$ & NATO 2006 \\
\hline Tibia Resulting Moment & $220 \mathrm{~N} * \mathrm{~m}$ & NATO 2006 \\
\hline
\end{tabular}

Placement of the charge relative to the vehicle is one of the critical decision points with respect to both landmine and bulk explosive testing. An under-wheel position is useful for evaluating vehicle motility, but is unlikely to produce casualties. An under-engine position is useful for evaluating the fire suppression system and increases burn and toxic gas inhalation hazards. The most hazardous charge placement for occupant survivability is under the occupant compartment; it is this position that will most severely test the performance of a vehicle design from a survivability perspective.

The test configuration for landmine and underbelly bulk tests is similar to that of the roadside IED tests, with a combination of pressure and thermal gages, shielded as needed from fragmentation effects, and visually recorded using a high-speed camera.

The vehicle should again be armoured as it is used in the field. On the vehicle, internal horizontal and vertical deformation measurements should be recorded pre and post test to assess the likelihood of injury. Horizontal measurements should be taken at the approximate level of the shoulder elbow and knee for each row of occupants. Vertical deformations should be taken at each occupant position at two locations, from the seat to the ceiling and from the floor directly in from where the feet would be located relative to the ceiling.

With respect to human surrogates, the Plywood Man should again be used for the landmine tests. However, for the bulk underbelly explosive, the SID or EuroSID used in the lateral bulk tests should be replaced with a Hybrid III ATD. The 
ATD should be centred on the seat with its hips firmly seated in the junction between the seat and back cushion. The ATD back should be flat against the seat back and the thigh resting evenly on the seat cushion the side-side angle should be zero with the head in an upright orientation. The feet should be firmly planted on the floor with no gap between the toes or heel.

Sample pass-fail criteria for both the landmine device and underbelly bulk explosive tests are similar to those presented for roadside IEDs and lateral bulk explosives. Sample ATD pass-fail criteria are provided in Table 6.

Table 6: $\quad$ ATD performance requirements for the lateral bulk tests.

\begin{tabular}{|l|l|l|}
\hline Times & Criteria & Rationale \\
\hline Head Injury Criteria & 700 & FMVSS 214 [20] \\
\hline Neck Injury Criteria & 1.0 & FMVSS 214 \\
\hline Torso & Criteria & \\
\hline Spine Acceleration & $60 \mathrm{~g}$ & FMVSS 214 \\
\hline Rib Displacement & $64 \mathrm{~mm}$ & FMVSS 214 \\
\hline Thoracic Trauma Index & 85 & FMVSS 214 \\
\hline Pelvis & Criteria & \\
\hline Lumbar load & $6800 \mathrm{~N}$ & \\
\hline Acceleration & $130 \mathrm{~g}$ & FMVSS 214 \\
\hline Dynamic Response Index & 16 & NATO 2006 [22] \\
\hline Lower Extremities & Criteria & \\
\hline Tibia Axial Force & $5,400 \mathrm{~N}$ & NATO 2006 \\
\hline Tibia Resulting Moment & $220 \mathrm{~N} * \mathrm{~m}$ & NATO 2006 \\
\hline
\end{tabular}

\section{Short-comings of existing technologies}

The majority of the existing injury criteria were developed for civilian automotive impacts. For application to military vehicles in a combat environment, there are two issues that must be considered: the directionality of the impact and the rate of impact. For military impacts, the risk of injury is likely omni-directional, including vertical impacts. In contrast, the existing criteria were designed assuming a limited number of impact orientations as are typical in civilian automotive crashes. The issue of directionality is of particular importance with neck injury criteria, which are highly suspect for lateral loads. The rate of impacts associated with local vehicle deformation is typically greater than the rate of impact that may be seen in civilian contexts. This factor is especially important in the assessment of thoracic injury criteria, but can also be important for other body regions.

A third issue in applying existing automotive and sports injury criteria in the blast environment is that most injury criteria were developed using the injury definitions from the 1998 AIS definitions. As a substantial redefinition of AIS has occurred since those definitions, the selected injury assessment values should be re-evaluated to determine if the new definitions have a substantial effect of the risk assessments. However, in the interim, the existing relationships are reasonable and will provide for a consistent basis for evaluating vehicle designs. 


\section{Conclusion}

In the coming years, the requirement for vehicles that are not only crashworthy, but also blast-worthy will continue. While vehicle designers have more than 35 years of automotive safety research to use in designing and testing for crashworthiness, there is relatively little data or research available to support blast-worthiness testing. The proposed methodology offers an approach to develop occupant survivability performance requirements for vehicles loaded by blast, which are quantitative, objective, medically grounded and experimentally verifiable. While testing standards have not yet been established for blastworthiness live fire testing, best practices have been developed which exploit existing injury criteria, human surrogates and instrumentation. Ultimately, advancements to the surrogates and their associated injury criteria will be required to accommodate the omni-directional nature of blast-loading and the higher rates of loading. In the meantime, judicious application of existing criteria and surrogates provides a means of objectively and quantitatively verifying the survivability of a vehicle loaded by blast.

\section{References}

[1] Blincoe, L., Seay, A., Zaloshnja, E., et al. The economic impact of motor vehicle crashes. Washington, DC: US Department of Transportation, National Highway Traffic Safety Administration, 2000.

[2] AAAM. The abbreviated injury scale, 1998 update, Association for the Advancement of Automotive Medicine, Des Plaines, IL, 1998.

[3] Meredith, J.W., Evans, G., Kilgo, P.D., et al. A comparison of the abilities of nine scoring algorithms in predicting mortality. J Trauma 2002; 53:621629.

[4] Price, G.R. and Kalb, J.T. "Development and validation of an Auditory Hazard Assessment Algorithm for the Human Ear as a predictor of hearing hazard and as an engineering tool", In: Report from NATO Research Study Group RSG.29(Panel 8 - AC/243) Reconsideration of effects of impulse noise, TNO-Report TM-00-I008, pp 6-10 (second meeting) 2000.

[5] Saucier, R. and Kash, H.M. III, ComputerMan Model Description, U.S. Army Research Laboratory ARL-TR-500, August 1994.

[6] Davis, E.G., Kennedy, C.M., Scott, L.P., Brief Overview of Army use of ballistic plywood manikin methodology and ordinance gelatin in soldier vulnerability ad survivability assessment. Briefing to the fourth meeting of blast injury testing conference, April, 2005.

[7] Knox, F.S.III, Bonetti, D., Perry, C., User manual for BRNSIM/BURMSIM: A bum hazard assessment model, USAARL Report No. 93-13, 1993.

[8] Prasad, P. \& Mertz, H.J., The position of the United States delegation to the ISO working group on the use of HIC in the automotive environment. SAE technical paper 851246, Society of Automotive Engineers, 1985. 
[9] Eppinger, R., Marcus, J.; Morgan, R. Development of dummy and injury index for NHTSA's thoracic side impact protection research program; Government/Industry Meeting and Exposition; Washington, DC., 1984.

[10] Viano, D.C., \& Lau, I.V., Thoracic impact: A viscous criterion. Tenth International Conference on Experimental Safety Vehicles. Oxford, England, 1985.

[11] Leport, T., Baudrit, P., Trosseille, X., Petit, P., Palisson, A., Vallancien, G., Assessment of the pubic force as a pelvic injury criterion in side impact. Stapp Car Crash J. 2007 Oct; 51:467-88, 2007.

[12] Mertz, H.J., Patrick, L.M., Strength and response of the human neck. SAE 710855 15th Stapp Car Crash Conference, 1971.

[13] Mertz, H. and Gadd, C., Thoracic tolerance and response to whole-body deceleration. SAE 710852, 15th Stapp Car Crash Conference, 1971

[14] Morgan, R., Eppinger, R.H., Marcus, J., Human Cadaver Patella-FemurPelvis Injury Due to Dynamic Frontal Impact to the Patella. The Twelfth International Conference on Experimental Safety Vehicles, 1989.

[15] Hirsch, A.H., Man's response to Shock Motion. Report 1797 David Taylor Model Basin Structural Mechanics Laboratory. Washington, DC, 1964.

[16] Horst, Marike van der, and Leerdam, P., "Occupant Safety for Blast Mine Detonation under Vehicles," 10th MADYMO Users Conference, 2003.

[17] Walilko, T.J., Performance Requirements and Sample Test Protocols. Technical reports prepared by Applied Research for the Office of Naval Research under Contract N00014-07-C-0076. April 7, 2008.

[18] James, D.J., Pichett, Y.C. Burdett, K.J., The response of the human ear to blast. Part 1: the effect on the ear drum of a "short" duration "fast" rising, Pressure wave. Joint AWRE/CCDE Report No. 04/82. Atomic weapons research establishment, Aldermaston, Berkshire, England, 1982.

[19] Bir, C.A., Steward, S.J., Wilhelm, M., Skin Penetration assessment of less lethal kinetic energy munitions. J Foresic Sci Nov; 50(6):1426-9, 2005.

[20] Federal Motor Vehicle Safety Standard No. 214, Code of Federal Regulations, Title 49, Part 572, Subpart A.

[21] Lau, I. and Viano, D.C., The viscous criterion - Bases and applications of an injury severity index for soft tissues. SAE 861882, 30th Stapp Car Crash Conference, 123-142, 1986.

[22] NATO Army Armaments Group, AEP-55 on Procedures for evaluating the protection level of logistic and light armoured vehicles PFP(NAAGLG/2)D(2006)0002, 2006. 